\title{
Pengaruh Penerapan Model Pembelajaran Eksploratif terhadap Kemampuan Representasi Matematis berdasarkan Kepercayaan Diri Siswa SMP
}

\author{
Agustina Anggraini ${ }^{1}$, Lies Andriani ${ }^{2}$ \\ ${ }^{1,3}$ Program Studi Pendidikan Matematika, Universitas Islam Negeri Sultan Syarif Kasim Riau \\ Jl. H. R. Soebrantas KM 15,5, Pekanbaru, Indonesia, 29283 \\ e-mail: lies.andriani@uin-suska.ac.id
}

\begin{abstract}
ABSTRAK. Penelitian ini bertujuan untuk mengetahui perbedaan kemampuan representasi matematis antara siswa yang mengikuti pembelajaran dengan model eksploratif dengan siswa yang mengikuti pembelajaran konvensional jika berdasarkan kepercayaan diri siswa SMP N 4 Tambang. Penelitian ini merupakan penelitian kuasi eksperimen dengan desain the nonequivalent pretest-posttest control group design. Sampel dipilih dengan teknik purposive sampling. Data dikumpulkan menggunakan tes kemmapuan representasi matematis, angket kepercayaan diri dan lembar observasi aktivitas guru dan siswa. Data yang diperoleh kemudian dianalisis menggunakan uji anova dua arah. Berdasarkan hasil analisis data dapat diambil kesimpulan bahwa: 1) Terdapat perbedaan kemampuan representasi matematis antara siswa yang mengikuti pembelajaran dengan model eksploratif dengan siswa yang memperoleh pembelajaran konvensional, 2) Terdapat perbedaan kemampuan representasi matematis siswa yang mengikuti pembelajaran dengan model eksploratif dengan siswa siswa yang memperoleh pembelajaran konvensional jika berdasarkan kepercayaan diri siswa, 3) Tidak terdapat pengaruh interaksi penerapan model pembelajaran dan kepercayaan diri siswa terhadap kemampuan representasi matematis siswa.
\end{abstract}

Kata kunci: model pembelajaran eksploratif, kemampuan representasi matematis, kepercayaan diri siswa.

\section{PENDAHULUAN}

Matematika merupakan salah satu ilmu mata pelajaran yang wajib dipelajari bagi siswa sekolah dasar dan menengah. Berdasarkan Permendikbud RI No. 58 Tahun 2014 (Permendikbud, 2014) pada butir ke 2 dinyatakan bahwa salah satu kemampuan yang harus dimiliki siswa adalah kemampuan representasi matematis. Yakni menggunakan pola sebagai dugaan dalam penyelesaian masalah, dan mampu membuat generalisasi berdasarkan fenomena atau data yang ada. Dengan demikian, kemampuan representasi matematis diperlukan siswa untuk menemukan dan mengembangkan cara berpikir dalam mengomunikasikan gagasan matematis dari yang sifatnya abstrak menuju konkrit, menggunakan bentuk sederhana seperti model matematika ataupun pola,sehingga masalah yang rumit dapat dilihat lebih mudah untuk dipahami.

Pentingnya representasi dalam pembelajaran matematika, juga ditunjukkan dalam standar proses yang ditetapkan The National Council of Teacher of Mathematics (NCTM). Dokumen Principles and Standards for School Mathematics yang dipublikasikan oleh NCTM pada tahun 2000 mendeskripsikan adanya keterkaitan antara kompetensi yang dimiliki siswa dengan pemahaman matematikanya. Standar proses yang termasuk kedalam NCTM adalah problem solving (kemampuan pemecahan masalah), reasoning and proof (kemampuan penalaran), communication (kemampuan komunikasi), connection (kemampuan koneksi matematis), dan representation (kemampuan representasi) (NCTM 2000).

Representasi merupakan bentuk interpretasi pemikiran siswa terhadap suatu masalah, yang digunakan sebagai alat bantu untuk menemukan solusi dari masalah tersebut. Bentuk interpretasi siswa dapat berupa kata-kata atau verbal, tulisan, gambar, tabel, grafik, benda konkrit, simbol 
matematika dan lain-lain (Sabirin, 2014). Hal ini sejalan dengan yang dijabarkan oleh Rangkuti (2015) bahwa representasi dibagi ke dalam tiga aspek, yaitu: (1) representasi visual, bentuk operasinal yang digunakan dalam penelitian ini adalah representasi visual gambar, (2) persamaan atau ekspresi matematis, bentuk operasional yang digunakan dalam penelitian ini adalah membuat penyelesaian masalah dari suatu ekspresi matematis, (3) kata-kata atau teks tertulis, bentuk operasional yang digunakan dalam penelitian ini adalah membuat situasi masalah berdasarkan data atau representasi yang diberikan serta membuat dan menjawab pertanyaan dengan menggunakan kata-kata. Secara operasional Pape \& Tchoshanov (2001) menjelaskan bahwa representasi dapat dideskripsikan setidaknya dalam empat gagasan pokok, yaitu: 1) representasi sebagai abstraksi internal dari ide-ide matematika atau skema kognitif yang dibangun oleh siswa melalui pengalaman; 2) representasi sebagai reproduksi mental dari keadaan mental yang sebelumnya; 3) representasi sebagai sajian ekivalensi struktur melalui gambar, simbol ataupun lambang; dan 4) representasi sebagai pengetahuan tentang sesuatu yang mewakili sesuatu yang lain.

Wijaya (2018) menyatakan bahwa kemampuan representasi matematis dibutuhkan oleh siswa dalam memahami materi yang diberikan dan menyelesaikan soal, jika kemampuan representasi matematis kurang maka menyebabkan kurangnya pemahaman siswa dalam materi yang diberikan sehingga siswa susah memahami dan mengerjakan soal yang disediakan. Kegiatankegiatan yang menunjang seorang siswa dalam memahami dan menggunakan ide-ide matematika dalam berbagai bentuk diagram, grafik ekspresi simbol, merupakan proses panjang dari representasi. Kegiatan-kegiatan yang menunjukkan representasi konsep tersebut merupakan sesuatu hal yang menjembatani penyelesaian persoalan matematika (Maryam, Isrok'atun \& Aeni, 2016). Sebagaimana dinyatakan Brenner (dalam Neria \& Amit, 2004) bahwa kemampuan seseorang dalam merepresentasikan masalah seperti mengkonstruksi dan menggunakan representasi matematik di dalam kata-kata, grafik, tabel, dan persamaan-persamaan, penyelesaian dan manipulasi simbol dapat menjadi ukuran suksesnya sebuah proses pemecahan masalah yang dilakukan oleh siswa.

Namun kenyataannya, kemampuan representasi matematis di Indonesia masih rendah. Hal ini ditunjukkan dengan kesalahan penggunaan bentuk representasi siswa dalam menyelesaikan masalah matematik. Hasil penelitian yang dilakukan oleh (Candriyana, Sujadi \& Riyadi (2016) menyimpulkan bahwa dalam menyelesaikan maslaah matematika, siswa cenderung menggunakan bentuk representasi simbolik, sayangnya jawaban-jawaban yang diberikan kurang tepat.

Mengingat pentingnya kemampuan representasi matematis untuk dimiliki siswa, dan bersama dengan itu pada kenyataannya kemampuan representasi matematis di Indonesia masih rendah, maka dibutuhkan suatu model pembelajaran untuk meningkatkan kemampuan representasi matematis. Kemampuan representasi matematis siswa dapat ditingkatkan melalui proses pembelajaran yang bersifat student centre, dimana guru bertindak sebagai fasilitator dan siswa melakukan eksplorasi sendiri terhadap kemampuan dan pemahaman yang dimilikinya. Menurut Piaget pembelajaran yang bermakna dapat terbentuk ketika siswa mengalami sendiri proses pembelajaran tersebut. Dalam hal ini, siswa terlibat secara penuh dalam proses pembelajaran yang dilakukan. Mengeksplorasi kemampuannya sendiri dalam memahami materi pembelajaran akan membuat siswa mengalami sendiri pembelajaran tersebut. Menurut Rahayu (2013) salah satu pembelajaran yang dapat membuat siswa mengalami sendiri pembelajaran tersebut adalah pembelajaran dengan menggunakan model pembelajaran eksploratif.

Menurut Isrok'atun dan Rosmala (2018) pembelajaran dengan model pembelajaran eksploratif memiliki empat tahapan, yaitu tahap penyajian masalah eksploratif, tahap pengumpulan data dan informasi, tahap analisis data, dan tahap mempresentasikan laporan hasil dan penyimpulan. Tahap penyajian masalah eksploratif dilakukan oleh guru sebagai fasilitator. Guru memberikan masalah yang dikemas dalam bentuk soal non rutin yang mampu memancing rasa keingintahuan siswa terhadap suatu permasalahan. Selanjutnya, pada tahapan pengumpulan data dan informasi dilakukan oleh siswa. Pada tahapan ini, siswa dilibatkan seluruhnya secara aktif dalam mencari informasi dan mengumpulkan data yang dapat membantu penyelesaian masalah 
yang diberikan oleh guru pada tahap penyajian masalah. Pada tahapan ini, kemampuan representasi siswa dapat terbentuk, karena siswa mencari tahu sendiri informasi yang dapat membantu penyelesaian masalah tersebut. Pada tahapan analisis data, siswa memiliki kesempatan secara aktif menggunakan pengetahuan dan kemampuan yang dimilikinya, dan dituntut untuk mampu menganalisis dan memecahkan masalah matematika berdasarkan pengetahuan dan kemampuan yang dimilikinya. Melalui kegiatan eksplorasi siswa dapat menemukan proses matematika sedemikian rupa sehingga siswa mengalami sendiri, mampu menciptakan suatu hipotesis, selanjutnya mencari jawaban untuk hipotesis yang siswa buat melalui kegiatan pengamatan.

Selain model pembelajaran yang digunakan, ada aspek lain yang mungkin mempengaruhi kemampuan kognitif siswa, salah satunya ialah kepercayaan diri (self confidence). Syam \& Amri (2017) berpendapat percaya diri atau self confidence adalah aspek kepribadian yang penting pada diri seseorang. Tanpa adanya kepercayaan diri maka akan banyak menimbulkan masalah pada diri seseorang. Kepercayaan diri merupakan atribut yang paling berharga pada diri seseorang dalam kehidupan bermasyarakat, karena dengan adanya kepercayaan diri, seseorang mampu mengaktualisasikan segala potensi yang ada di dalam dirinya. Perbedaan tingkat percaya diri yang dimiliki individu tentu akan mempengaruhi perolehan prestasi belajar. Individu yang memiliki percaya diri yang tinggi akan memperoleh prestasi yang baik karena selalu beranggapan positif dan percaya terhadap kemampuan diri sendiri.

Berdasarkan pemaparan di atas, maka kita dapat melihat bahwa kemampuan representasi matematis siswa harus dikembangkan. Kemampuan ini mungkin dipengaruhi oleh model pembelajaran yang digunakan guru, salah satunya model pembelajaran eksploratif, serta tingkat kepercayaan diri siswa. Oleh sebab itu, peneliti melakukan penelitian yang bertujuan untuk melihat pengaruh model pembelajaran eksploratif terhadap kemampuan representasi matematis berdasarkan kepercayaan diri siswa.

\section{METODE}

Jenis penelitian ini adalah quasi experimental. Dikatakan quasi eksperimental karena penelitian ini tidak dapat mengontrol semua faktor yang terdapat dalam penelitian. Desain penelitian yang digunakan adalah the nonequivalent pretest-posttest control group design karena peneliti ingin melihat perbedaan kemampuan representasi matematis yang dimiliki siswa sebelum dan sesudah penelitian. Populasi dalam penelitian ini adalah seluruh siswa kelas VIII SMPN 4 Tambang tahun ajaran 2018/2019. Sampel terpilih adalah kelas VIII-D dan VIII-E. Teknik pengambilan sampel menggunakan teknik purposive sampling dengan menggunakan pertimbangan dari guru terhadap pengambilan sampel dari populasi yang akan diteliti.

Instrumen dalam penelitian ini adalah tes kemampuan representasi matematis siswa, angket kepercayaan diri, serta lembar observasi guru dan siswa. Kualitas dari suatu instrumen penelitian dapat mempengaruhi kualitas hasil penelitian. Oleh karena itu, instrumen penelitian tes Untuk kepercayaan diri siswa, angket diberikan di awal pada kelompok eksperimen dan kelompok kontrol. Skala kepercayaan diri siswa dikelompokkan menjadi tinggi, sedang dan rendah. Kriteria pengelompokan kepercayaan diri siswa ditentukan sebagai berikut (Muhandaz, Trisnawita \& Risnawati, 2018)

Tabel 1. Kriteria Penilaian Kepercayaan Diri

\begin{tabular}{cc}
\hline Kriteria & Kategori \\
\hline$S R L \geq \bar{X}+S$ & Kelompok Tinggi \\
$\bar{X}-S<S R L<\bar{X}+S$ & Kelompok Sedang \\
$\bar{X}-S \leq S R L$ & Kelompok Rendah \\
\hline
\end{tabular}

Teknik analisis data yang digunakan untuk menguji hipotesis 1, 2 dan 3 menggunakan Anova dua arah. Anova dua arah dapat digunakan untuk menguji hipotesis yang membandingkan 
perbedaan rata-rata dari sampel yang independen dengan melibatkan dua faktor atau lebih, dan untuk melihat pengaruh/interaksi antara dua faktor yang terdiri dari dua atau lebih kategori terhadap suatu variabel lain. Hipotesis dalam penelitian ini sebagai berikut:

\section{Hipotesis I}

Ho : Tidak terdapat perbedaan kemampuan representasi matematis antara siswa yang mengikuti pembelajaran dengan model eksploratif dengan siswa yang mengikuti pembelajaran konvensional.

$\mathrm{Ha}$ : Terdapat perbedaan kemampuan representasi matematis antara siswa yang mengikuti pembelajaran dengan model eksploratif dengan siswa yang mengikuti pembelajaran konvensional.

\section{Hipotesis II}

Ho : Tidak terdapat perbedaan kemampuan representasi matematis siswa yang mengikuti pembelajaran dengan model eksploratif dengan siswa yang mengikuti pembelajaran konvensional.

$\mathrm{Ha}$ : Terdapat perbedaan kemampuan representasi matematis siswa yang mengikuti pembelajaran dengan model eksploratif dengan siswa yang mengikuti pembelajaran konvensional jika berdasarkan kepercayaan diri siswa.

\section{Hipotesis III}

Ho : Tidak terdapat interaksi penerapan model pembelajaran dan kepercayaan diri terhadap kemampuan representasi matematis siswa.

$\mathrm{Ha}$ : Terdapat interaksi penerapan model pembelajaran dan kepercayaan diri terhadap kemampuan representasi matematis siswa.

\section{HASIL DAN PEMBAHASAN}

\section{Hasil}

Sebelum membahas hasil uji hipotesis penelitian, berikut dipaparkan hasil observasi aktivitas guru dan siswa selama penelitian. Diagram berikut menunjukkan persentase keterlaksanaan model eksploratif yang dilakukan guru.

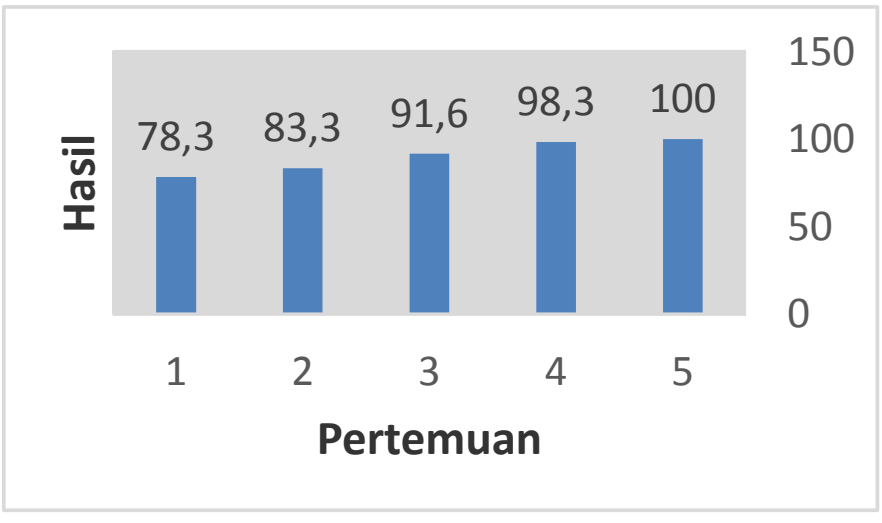

\section{Gambar 1. Persentase Keterlaksanaan Aktivitas Guru pada Model Eksploratif}

Berdasarkan gambar 1 tampak bahwa keterlaksaan aktivitas guru menggunakan model eksploratif dalam setiap pertemuan mengalami peningkatan. Pertemuan pertama, guru masih terlihat seperti ragu dalam menerapkan model eksploratif di dalam kelas. Terlihat dari adanya beberapa langkah dalam proses pembelajaran yang tidak terlaksana. Namun, pertemuan kedua dan seterusnya guru mulai mampu menguasai kelas dan langkah-langkah pembelajaran model 
eksploratif yang terlaksana seluruhnya. Selanjutnya, pada gambar berikut ditunjukkan persentase keterlaksanaan model eksploratif oleh siswa di setiap pertemuan.

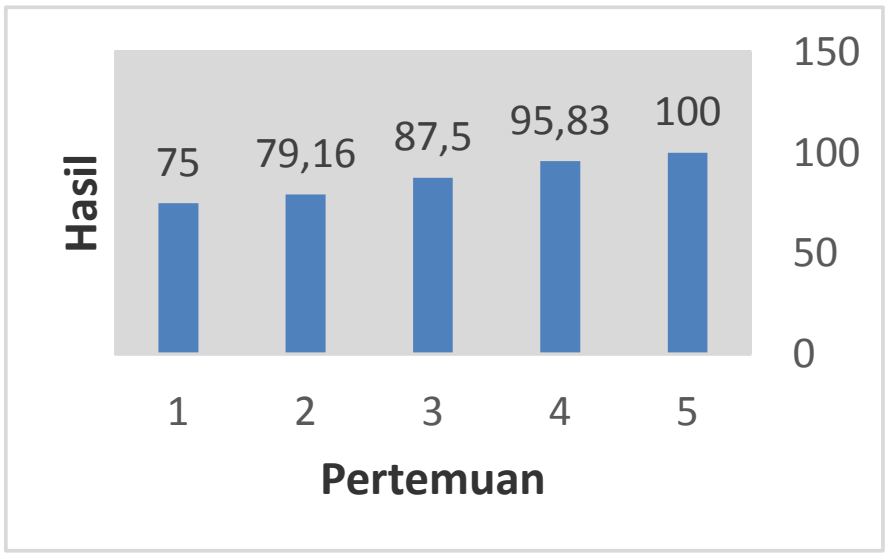

Gambar 2. Persentase Keterlaksanaan Aktivitas Siswa pada Model Eksploratif

Berdasarkan gambar 2, keterlaksanaan aktivitas siswa dengan menggunakan model eksploratif sangat baik dilihat dari peningkatan setiap pertemuan. Siswa yang mulanya masih malu bertanya dan cenderung pasif pada pertemuan awal, dengan model eksploratif yang menuntut siswa aktif bertanya dan memberikan pernyataan membuat aktivitas belajar menjadi lebih hidup dalam setiap pertemuan. Karena pada pertemuan ke-5, baik aktivitas guru maupun siswa sudah terlaksana 100\%, maka pada pertemuan berikutnya dilaksanakan posttest untuk mengukur kemampuan representasi matematis siswa. Rata-rata hasil uji kemampuan representasi matematis siswa kelas kontrol dan kelas eksperimen dapat di lihat pada gambar berikut:

Tabel 2. Rata-Rata Hasil Uji Kemampuan Representasi Matematis

\begin{tabular}{cccc|c}
\hline Kelompok & $\mathbf{x}_{\max }$ & $\mathbf{x}_{\min }$ & Rata-rata & Standar Deviasi \\
\hline Kontrol & 91 & 48 & 69,2 & 12,57 \\
Eksperimen & 100 & 62 & 74,7 & 10,38 \\
\hline
\end{tabular}

Dari table 2, terlihat bahwa rata-rata kemampuan representasi matematis siswa kelompok eksperimen lebih tinggi 5,5 poin dibanding kelompok kontrol. Untuk memastikan signifikansi perbedaan tersebut maka akan dilakukan uji statistik terhadap rata-rata kedua kelompok. Sebelumnya, akan dilakukan uji normalitas dan uji homogenitas untuk menentukan uji statistik yang akan digunakan. Uji normalitas menggunakan uji lilifors dan sedangkan uji homogenitas menggunakan rumus Uji F. Berikut hasil uji normalitas dan uji homogenitas posttest.

Tabel 3. Hasil Uji Normalitas Posttest

\begin{tabular}{cccl}
\hline Kelompok & $\boldsymbol{L}_{\text {hitung }}$ & $\boldsymbol{L}_{\boldsymbol{t a b e l}}$ & Kriteria \\
\hline Eksperimen & $-0,011$ & 0,161 & Normal \\
Kontrol & 0,029 & 0,161 & Normal \\
\hline
\end{tabular}

Dengan $\boldsymbol{L}_{\text {hitung }}<\boldsymbol{L}_{\text {tabel }}$, maka data berdistribusi normal. Sehingga disimpulkan bahwa rata-rata kedua kelompok berdistribusi normal. Selanjutnya dilakukan uji homogenitas varians kedua kelompok.

Tabel 4. Hasil Uji Homogenitas Posttest

\begin{tabular}{ccccc}
\hline Nilai Varians & Eksperimen & Kontrol & $\boldsymbol{F}_{\text {hitung }}$ & $\boldsymbol{F}_{\text {tabel }}$ \\
\hline$s^{2}$ & 107,842 & 162,682 & 1,508 & 1,92 \\
$\mathrm{~N}$ & 26 & 28 & & \\
\hline
\end{tabular}


Dapat dilihat dari tabel di atas bahwa $F_{\text {hitung }}<F_{\text {tabel }}$, maka dapat diartikan bahwa kedua kelompok bervariansi homogen. Karena rata-rata kedua kelompok terdistribusi normal dan bervariansi homogen dan melibatkan lebih dari dua variabel, maka uji hipotesis dilakukan dengan anova dua arah. Hasil pengujian dengan anova dua arah dapat dilihat pada berikut:

Tabel 4. Hasil Uji Anova Dua Arah

\begin{tabular}{cccccc}
\hline Varians & dk & JK & RK & Fh & Fk \\
\hline A & 1 & 1934,23 & 1934,230 & 14,499 & 4,04 \\
B & 2 & 892,91 & 446,457 & 3,347 & 3,19 \\
A x B & 2 & $-95,38$ & $-47,688$ & $-0,357$ & 3,19 \\
\hline
\end{tabular}

Berdasarkan tabel 4 untuk hipotesis pertama, baris pertama menyatakan pengaruh dari model eksploratif, hasilnya $F(A)_{\text {hitung }}>F(A)_{\text {tabel }}$ maka $H_{a}$ diterima sehingga disimpulkan bahwa pada taraf signifikan $5 \%$ terdapat perbedaan kemampuan representasi matematis antara siswa yang mengikuti pembelajaran dengan model eksploratif dengan siswa yang memperoleh pembelajaran konvensional. Selanjutnya, untuk hipotesis kedua, baris kedua menyatakan pengaruh dari model eksploratif jika ditinjau dari kepercayaan diri siswa, hasilnya $F(B)_{\text {hitung }}>F(B)_{\text {tabel }}$ maka $H_{a}$ diterima. Artinya, pada taraf signifikan $5 \%$ terdapat perbedaan kemampuan representasi matematis siswa yang mengikuti pembelajaran dengan model eksploratif dengan siswa yang tidak mengikuti pembelajaran dengan model eksploratif jika berdasarkan kepercayaan diri siswa. Untuk hiotesis ketiga, baris ketiga menyatakan interaksi dari penerapan model pembelajaran dan kepercayaan diri siswa terhadap kemampuan representasi matematis siswa. Hasilnya $F(A x B)_{\text {hitung }}<F(A x B)_{\text {tabel }}$ maka $H_{o}$ diterima. Jadi, pada taraf signifikan $5 \%$ tidak terdapat interaksi penerapan model pembelajaran dan kepercayaan diri siswa terhadap kemampuan representasi matematis siswa.

\section{Pembahasan}

Sebagaimana telah dipaparkan bahwa penelitian ini bertujuan untuk melihat apakah pengaruh model eksploratif terhadap kemampuan representasi matematis ditinjau dari kepercayaan diri siswa. Hasil analisis data menunjukkan bahwa terdapat perbedaan yang signifikan kemampuan representasi matematis antara siswa yang belajar dengan model eksploratif dengan siswa yang belajar memperoleh pembelajaran konvensional. Hal ini menunjukkan pengaruh model pembelajaran eksploratif terhadap kemampuan matematis siswa. Hal ini dikarenakan model eksploratif menuntut siswa untuk mengeksplorasi kemampuan kognitifnya sendiri.

Melalui tahapan-tahapan model pembelajaran eksploratif, guru dapat memfasilitasi kemampuan representasi matematisnya. Tahapan pertama, yaitu tahap penyajian masalah yang dikemas dalam bentuk soal non rutin yang mampu memancing rasa keingintahuan siswa terhadap suatu permasalahan. Pada tahapan ini guru membimbing siswa untuk memahami masalah. Sebagaimana yang disebutkan oleh Mardaleni, Noviarni \& Nurdin (2018) bahwa untuk membantu siswa menyelesaikan masalah, maka guru harus mampu membimbing siswa untuk benar-benar memahami masalah hingga menemukan solusi penyelesaian. Artinya, melalui tahapan pertama ini siswa akhirnya mampu memahami masalah dengan bimbingan dari guru dan dapat merencanakan atau membuat daftar informasi atau data yang harus mereka kumpulkan pada tahap selanjutnya. Pada tahapan ini, siswa dilibatkan seluruhnya secara aktif dalam mencari informasi dan mengumpulkan data yang dapat membantu penyelesaian masalah yang diberikan oleh guru pada tahap penyajian masalah. Dengan partisipasi aktif oleh siswa dalam mencari informasi akan membangun pengetahuan siswa berdasarkan pengalamannya (Nurdin, Risnawati \& Ayurila, 2018). Pada tahapan ini, kemampuan representasi siswa dapat terbentuk, karena siswa mencari tahu sendiri informasi yang dapat membantu penyelesaian masalah tersebut. Pada tahapan analisis data, siswa memiliki kesempatan secara aktif menggunakan pengetahuan dan kemampuan yang dimilikinya, dan dituntut untuk mampu menganalisis dan memecahkan masalah matematika berdasarkan pengetahuan dan kemampuan yang dimilikinya. Melalui kegiatan eksplorasi siswa 
dapat menemukan proses matematika sedemikian rupa sehingga siswa mengalami sendiri, mampu menciptakan suatu hipotesis, selanjutnya mencari jawaban untuk hipotesis yang siswa buat melalui kegiatan pengamatan. Siswa dapat berdiskusi dengan temannya, bersama-sama menganalisis hasil yang mereka peroleh. Melalui diskusi siswa dapat meningkatkan kemampuannya dalam menyampaikan gagasan dan pemikirannya baik kepada teman maupun gurunya (Siregar, Risnawati \& Nurdin, 2018). Kegiatan-kegiatan yang dilakukan siswa bersama guru dalam pembelajaran eksploratif tersebut mampu memfasilitasi kemampuan representasi matematis siswa.

Hasil penelitian yang diperoleh pada penelitian ini juga sejalan dan mendukung penelitian yang dilakukan oleh Gelar (2013). Ia menyimpulkan bahwa strategi pembelajaran eksploratif dalam penelitian ini dapat memberikan suasana belajar yang baru bagi siswa, karena siswa dituntut untuk kreatif melalui aktifitas eksplorasi. Menurut Maryam, Isrok'atun \& Aeni (2016), hal ini disebabkan oleh respon siswa yang sangat positif dilihat dari aktivitas siswa yang terus menerus meningkat di mulai dari keterlibatan keaktifan siswa dalam proses pembelajaran, antusiasme siswa terhadap pembelajaran, dan lembar aktivitas siswa (LAS) yang diberikan oleh guru dikerjakan sesuai prosedur. Jadi, dapat disimpulkan bahwa model pembalajaran eksploratif yang digunakan guru pada proses pembelajaran yang bersifat student center atau kegiatan pembelajaran yang berpusat pada guru membuat siswa terlibat secara aktif. Suasana pembelajaran yang tercipta juga menjadi lebih hidup. Karena, guru tidak lagi menjelaskan secara penuh di depan kelas dan siswa hanya duduk diam mendengarkan penjelasan. Dengan kata lain, guru hanyalah fasilitator terhadap kegiatan pembelajara tersebut, membantu siswa yang kebingungan dalam mencari jawaban untuk hipotesis yang dibuat siswa dalam penyelesaian masalah serta bersama-sama dengan siswa menarik kesimpulan terhadap suatu permasalahan matematika.

Hasil uji anova dua arah menunjukkan bahwa terdapat perbedaan signifikan antara siswa yang menggunakan model eksploratif dengan siswa yang memperoleh pembelajaran konvensional jika ditinjau dari kepercayaan diri siswa. Dan hasil analisis menggunakan uji anova dua arah menunjukkan tidak terdapat interaksi antara model pembelajaran dengan kepercayaan diri dalam mempengaruhi kemampuan representasi matematis siswa. Dengan demikian dapat disimpulkan bahwa model pembelajaran terhadap kemampuan representasi matematis siswa tidak bergantung pada kepercayaan diri, dan kepercayan diri terhadap kemampuan representasi matematis siswa tidak bergantung pada model pembelajaran yang digunakan, hal ini menunjukkan bahwa model pembelajaran dan kepercayaan diri mempunyai posisi sendiri terhadap kemampuan representasi matematis siswa. Hal ini sejalan dengan apa yang dikemukakan oleh Panitz (2019) bahwa tidak terjadinya interaksi antara model pembelajaran dan variabel moderator terhadap variabel terikat karena adanya pengaruh utama yang kuat dari variabel bebas dan variabel moderator terhadap variabel terikat, sehingga melemahkan interaksi yang ada.

\section{REFERENSI}

Cahdriyana, R. A., Sujadi, I., \& Riyadi. (2014). Representasi matematis siswa kelas VII di SMPN 9 Yogyakarta dalam membangun konsep SPLDV. Jumal Elektronik Pembelajaran Matematika, 2(6), 632-642.

Gelar, D.R. (2013). Pengaruh strategi pembelajaran eksploratif terhadap peningkatan kemampuan visualisasi, pemahaman konsep geometri, dan karakter siswa. Disertasi Pascasarjana UPI Bandung.

Isrok'atun., \& Rosmala, A. (2018). Model-model pembelajaran matematika. Jakarta: Bumi Aksara

Kementrian Pendidikan Dan Kebudayaan, Peraturan Menteri Pendidikan Dan Kebudayaan Republik Indonesia Nomor 58 Tahun 2014, Jakarta. Hal. 325-327. 
Maryam, S., Isrok'atun., \& Aeni, A. N. (2016). Pendekatan eksploratif untuk meningkatkan kemampuan representasi matematis dan kepercayaan diri siswa. Jurnal Pena Ilmiah, 1(1), 551 560 .

Mardaleni, D., Noviarni., \& Nurdin, E. (2018). Efek strategi pembelajaran scaffolding terhadap kemampuan pemecahan masalah matematis berdasarkan kemampuan awal matematis siswa. JURING (Journal for Research in Mathematics Education), 1(3), 236-241.

Muhandaz, R., Trisnawita, O \& Risnawati.(2018). Pengaruh Model Pembelajaran Course Review Horay terhadap Kemampuan Pemahaman Konsep Matematis Berdasarkan Kemandirian Belajar Siswa SMK Pekanbaru. Juring (Journal for Research in Mathematics Learning), 1(2), 137 146

National Council of Teachers of Mathematics. 2000. Principles and Standards for School Mathematics. Reston, VA: NCTM.

Neria, D., \& Amit, M. (2004). Students Preference of non-algebraic representations in mathematical communication. Proceedings of the 28th conference of the international group for the psychology of mathematical education, 3, $409-416$.

Nurdin, E., Ayurila, M., \& Risnawati. (2018). Pengembangan lembar kerja siswa berbasis group investigation untuk memfasilitasi kemampuan penalaran matematis siswa SMP. JURING Journal for Research in Mathematics Education), 1(3), 219-226.

Panitz. $\mathrm{T}$ Benefits of Corperative Learning in Relation to Student Motivation. (online). http://home.capecod.net/ tpanitz/tedsarticles/motivation.html. Diakses 19 Agustus 2019

Pape, S.J. \& Tchoshanov, M.A. (2001). The role of representation(s) in developing mathematical understanding. Theory into Practice, 40(2), 118-125

Rangkuti, A.N. (2015). Representasi matematis. Logaritma: Jurnal Ilmu-ilmu Penddidikan dan Sains, $1(02), 1-11$.

Sabirin, M. (2014). Representasi dalam pembelajaran matematika. Jurnal Pendidikan Matematika UIN Antasari, 1(2), 33-44.

Siregar, A.P., Risnawati., \& Nurdin, E. (2018). Pengembangan lembar kerja siswa berbasis generative learning untuk memfasilitasi kemampuan komunikasi matematis siswa sekolah menengah pertama kampar. JURING (Journal for Research in Mathematics Education), 1(2), 111 118.

Syam, A., \& Amri, A. (2017). Pengaruh kepercayaan diri (self confidence) berbasis kaderisasi IMM terhadap prestasi belajar mahasiswa (studi kasus di program studi pendidikan biologi fakultas keguruan dan ilmu pendidikan universitas muhammadiyah parepare). Jurnal Biotek, 5(1), 87-102.

Wijaya, C.B. (2018). Analisis kemampuan representasi matematis siswa dalam menyelesaikan soal lingkaran pada kelas VII-B MTs Assyafi'iyah Gondang. Suska Journal of Mathematics Education, 4(2), 115-124. 